\title{
COST-EFFECTIVENESS ANALYSIS OF ETANERCEPT IN COMBINATION WITH METHOTREXATE FOR RHEUMATOID ARTHRITIS - MARKOV MODEL BASED ON DATA FROM SERBIA
}

\author{
Marina Kostic
}

University of Kragujevac, Serbia, Faculty of Medical Sciences, Department of Pharmacology and Toxicology

\author{
ANALIZA ODNOSA TROŠKOVA I EFEKATA ETARNECEPTA U \\ KOMBINACIJI SA METOTREKSATOM U LEČENJU REUMATOIDNOG \\ ARTRITISA - MARIKOVLJEV MODEL BAZIRAN NA PODACIMA IZ SRBIJE \\ Marina Kostić \\ Univerzitet u Kragujevcu, Fakultet medicinskih nauka, Katedra za Farmakologiju i toksikologiju
}

\begin{abstract}
Biological therapeutic strategies have shown positive benefits for chronic and progressive rheumatoid arthritis (RA) in clinical and radiological outcomes. Despite these results, the use of biological drugs in the treatment of $R A$ is limited by high costs. The aim of this study was to compare the cost effectiveness of etanercept in combination with methotrexate and methotrexate alone in patients with $R A$ in the socioeconomic environment of a Balkan country.

We conducted a cost-effectiveness study using a Markov model from a societal perspective with a time horizon of 480 months. The cycle duration was set to one month. The basic transition probabilities and data on therapeutic efficacy were estimated from the available literature, while costs were calculated using the medical documents of patients with RA treated at the Clinical Center Kragujevac.
\end{abstract}

Our results indicated that treatment of patients with $R A$ using methotrexate alone is more cost effective, with a cost-effectiveness ratio of 1.446.640,78 RSD/QALY, than treatment with a combination of methotrexate and etanercept, with a cost-effectiveness ratio of 5.882.714,57 RSD/QALY.

The use of etanercept to treat $R A$ is not cost effective in the socioeconomic environment of Serbia. The cost-effectiveness ratio of biological drugs would be more favourable if special strategies for the pricing policy of biological drugs were established on the basis of local pharmacoeconomic studies.

Keywords: rheumatoid arthritis; biological therapy; etanercept, cost-effectiveness analysis

\section{SAŽETAK}

Primena bioloških lekova u lečenju reumatoidnog artritisa doprinosi promeni progresivnog toka ove bolesti kako u kliničkom tako i u radiološkom smislu a uz to popravlja i funkcionalnu sposobnost obolelih. Pa ipak, primena biološke terapije u lečenju reumatoidnog artritisa je ograničena visokim troškovima koji prate upotrebu ovakvih lekova. Cilj ovog istraživanja je bio da se uporede troškovi $i$ efekti kombinacije etanercepta $i$ metotreksata sa primenom metotreksata u lečenju reumatoidnog artritisa u farmakoekonomskim uslovima u Srbiji.

Za potrebe ovog istraživanja konstruisan je Markovljev model u kojem je predstavljena hronična priroda i progresivan tok reumatoidnog artritisa, a bazične, tranzicione verovatnoće $i$ efikasnost etanercepta $i$ metotreksata su procenjene na osnovu podataka iz dostupne literature. $\mathrm{Za}$ potrebe ovog istraživanja procenjeni su troškovi lečenja pacijenata obolelih od reumatoidnog artritisa, a na osnovu dostupne dokumentacije iz Kliničkog centra Kragujevac. Istraživanje je sprovedeno sa aspekta društva u celini, a u troškove $i$ ishode je uključena diskontna stopa od 3\%. Vremenski horizont je iznosio 40 godina, a jedan ciklus u modelu je trajao 1 mesec.

Ukoliko se sagleda odnos troškova i efekata, lečenje reumatoidnog artritisa metotreksatom je povoljnije nego lečenje iste bolesti kombinacijom metotreksata i etanercepta s' obzirom da vrednost odnosa troškova i efekata za etanercept u kombinaciji sa metotreksatom iznosi 5.882.714,57 RSD/QALY dok vrednost odnosa troškova i efekata za monoterapiju metotreksatom iznosi 1.446.640,78 RSD/QALY.

Odnos troškova i efekata etanercepta u kombinaciji sa metotreksatom ukazuje da je primena biološke terapije u lečenju reumatoidnog artritisa neisplativa u socio-ekonomskim uslovima u Srbiji.

Ključne reči: reumatoidni arthritis; biološka terapija; etarnecept; analiza odnosa troškova i efekata

\section{ABBREVIATIONS}

ACR - American College of Rheumatology bDMARDs - Biological Disease-modifying antirheumatic drugs cDMARDS-conventional DMARD-s

DAS28 - Disease Activity Score DMARDs - Disease-modifying antirheumatic drugs IL-1 - Interleukin-1
IL-6 - Interleukin-6

ICER - Incremental cost-effectiveness ratio HAQ - Health Assessment Questionnaire NICE - National Institute for Clinical Excellence QALY - Quality-adjusted life year RA - Rheumatoid arthritis 


\section{INTRODUCTION}

Rheumatoid arthritis (RA) is a systematic, autoimmune disease with chronic course that mainly affect joints but also leads to deterioration of multiple organs, decreasing the quality of life of patients causing increased mortality (1). RA affects $0.5-1 \%$ of the general population. As is the case with many autoimmune diseases, the aetiology of RA is partly known. The main aetiological factors are heredity, gender, environmental factors and infectious agents (2). RA affects women 3 to 4 times more often than men, with tendency to increase with age (3). Since the onset of RA occurs during the economically productive phase of life, the socioeconomic burden in terms of costs (direct and indirect), reduced work ability, long-term disability and morbidity, is substantial $(4,5)$. RA has a significant impact on the quality of life of patients and results in a considerable burden for patients. Early diagnosis of RA is crucial for timely introduction of drugs to achieve and maintain remission in patients (2).

In 1978, the American College of Rheumatology (ACR) established criteria to diagnose RA, where 4 of the 7 following criteria must be present: morning stiffness, arthritis in 3 or more joint areas, arthritis of the hand joints (more than 1 joint), symmetrical arthritis, rheumatoid nodules, elevated serum rheumatoid factor and typical radiographic changes (with the exception for the two last criteria, the changes must persist for at least 6 weeks) (6). In 2010, the European League for Rheumatoid Arthritis recommended amendments to the ACR criteria since they lack criteria for early arthritis and for newly diagnosed patients with clinical presentation with synovitis and edema within one joint and patients with synovitis where aetiology is not determinate (7). RA is a clinical entity whose chronic nature and progressive course leads to structural and functional damage of both the affected joints and the surrounding tissue and bones. Due to the variable and progressive nature of RA, different measurement instruments have been developed to estimate disease activity and the disability of patients and to monitor treatment outcomes. The Disease Activity Score (DAS28) is the "gold standard" for estimating disease activity, with values greater than 5.1 for very active disease, from 3.6 to 5.1 for moderate disease activity and less than 3.6 for inactive disease. DAS28 can also been used to assess a patient's response to therapy and achieving a state of remission. The Health Assesment Questionaire (HAQ score) is the dominant technique used to assess the functional inability of patients with RA in terms of inability, pain and discomfort, adverse reactions to drugs and economic sphere of treating RA, with values ranging from zero to three, where zero represents a state without disability and three represents a state of full disability $(8,9)$.

The new therapeutic concept of RA ("treat to target") is directed to better control disease activity by modifying the dose and course of therapy according to the values of disease activity. Therapeutic strategies used in RA include a wide palette of drugs known as disease-modifying antirheumatic drugs (DMARDs), which can be divided into synthetic DMARDs and biological DMARDs. Synthetic DMARDs include two large groups: conventional DMARDs (cDMARDs) and targeted DMARDs (2). The core of therapy for RA is the cDMARDs $i$, methotrexate, but the final response of patients can be inadequate due to inefficacy or toxicity (10). Biological DMARDs target parts of the immunopathogenic pathway in the pathogenesis of RA, such as tumour necrosis factor $\alpha$ (TNF- $\alpha$ ) (infliximab, etanercept, adalimumab), interleukin-1 (IL-1) (anankira), interleukin-6 (IL-6) (tocilizumab), and costimulatory factors CD 20 (rituximab) (10,11). Despite proven efficacy, the introduction of biological therapy is limited by its high costs in countries with recent socioeconomic transition and in other countries, with recommendations similar to those given by the National Institute for Clinical Excellence (NICE) from the U.K.: treatment with biologic medicine (mostly with a TNF blocker) is given to a patient whose response to methotrexate is poor and incomplete; if there is no response to the first biologic medicine after 3 to 6 months of treatment, the patient should be switched to another biologic medicine (2).

Cost-effectiveness analyses are crucial to estimate the costs and efficacy of biological drugs, such as etanercept.

The aim of this study was to compare the cost-effectiveness of two therapeutic strategies in patients with RA: treatment with cDMARDs alone or in combination with etanercept, using a Markov model based on efficacy data from published clinical trials and costs sampled from the economic environment in Serbia

\section{MATERIAL AND METHODS}

We constructed a Markov model to compare the cost effectiveness of etanercept in combination with MTX and MTX alone in patients with RA. The model was constructed using TreeAge Pro instead ${ }^{\circ}$ software, version 2006 (12). Therapeutic strategies were compared using a set of scenarios representing a chronic and progressive course of RA. In our model, five health states were presented using HAQ, similar to the study of Kobelt et al. (15). These states represent the chronic nature and variable course of RA: HAQ score less than 0.6, HAQ score from 0.6 to 1.1, HAQ score from 1.1 to 1.6, HAQ score from 1.6 to 2.1 and HAQ scores higher than 2.1. For every state, we included death as a potential state. Disease activity was incorporated into the model by dividing each health state into two sub-states: one with high and another with low activity. In our model, death was the only definitive state, so a virtual cohort of 1000 patient could move from one state to another depending on the natural course of the disease and experiences from clinical trials. For every therapeutic strategy compared in the model, we assigned the initial patient distributions, transitional probabilities, utilities, and effectiveness, which were obtained from the available literature $(13,14)$. The economic aspects of each therapeutic 
strategy were represented by the costs of the health states and were calculated using the records of actual patients treated at the Clinical Center Kragujevac, Serbia. Pharmacoecomic modelling research requires definition of the time aspects in which the compared therapeutic strategies are analysed; in our model, the time horizon was set to 40 years (480 months), with a cycle duration of one month because of the chronic nature of RA. The perspective in our model was societal since direct and indirect costs were included due to their importance in the socioeconomic burden of RA. All costs and outcomes were discounted by $3 \%$ annually. For the purposes of modelling, we conducted a pilot study to estimate the costs of RA. Patients were randomly selected from the population of patients with RA treated at the Clinical Center Kragujevac, Serbia, during one year (from June 2009 to June 2010). Patients were offered the opportunity to participate in an interview regarding potential resource items. The patients entered their data anonymously to protect their identities. No patient received financial reward for participating. Using interview techniques, we estimated data about direct costs (costs of medical exams, diagnostic procedures, medicines, and hospitalizations) and indirect cost (e.g., costs of transportation and lost wages). Data on health service utilizations were estimated separately from the medical files of patients for every HAQ state in our model and every disease activity sub-state. The sources for the prices of health services were the databases from the Republic Institute for Health Insurance (RIHI) Tariff Book, and the prices of medicines were obtained from the list of medicines financed by the RIHI issued in 2010 (15). All costs were expressed in Serbian dinars (RSD). We followed the following outcomes: gains in utility for each therapy option expressed as QALYs gained and total and mean costs for every therapeutic option in our model. The modelling process requires a definition of willingness to pay, i.e., how much a society is willing to pay for one quality-adjusted life year (QALY) gained from a specific disease treatment. In our model, we used the recommendation that the value of willingness to pay should be equal to two to three times the gross national income per capita. In the case of Serbia, the gross national income per capita (GDP/capita) was 563,400 dinars (RSD) (16). We also used the average monthly net income in Serbia to calculate the costs of lost wages.

We performed Monte Carlo simulations using a microsimulation trial, where cohorts of 1,000 virtual patients passed through all hypothetical scenarios. The results of the Monte Carlo simulation were summarized using the incremental cost-effectiveness ratio (ICER) $(17,18)$. For each therapeutic option, we calculated the mean costs and the mean effects and expressed them as the cost-effectiveness ratio. To determine the robustness of the results of our model, we performed two-way sensitivity analysis.

\section{RESULTS:}

The results of the pilot study indicate that the cost of treating patients with cDMARDs (MTX) for one year was on average 261,945.42 RSD or 2,113.26 Euro, and the total cost for treating patients with etanercept in combination with MTX was on average 1509 533,002 RSD (12,178.26 Euro) (Figure 1).

We used the cost-effectiveness calculation method to compare both RA therapeutic strategies in terms of the total costs and QALY. The results of this analysis show that cDMARDs (MTX) require much less investment than the biological drug etanercept in combination with MTX. The total gain expressed in QALY was higher in the group with etanercept in combination with MTX.

The total cost for one statistical patient treated with MTX for the total time horizon of 40 years was 7,788,768.97 RSD, and the total cost for one statistical patient treated with etanercept in combination with MTX for the total time horizon of 40 years was 34,870,470.29 RSD. Total gain expressed in QALY in the same setting was 5.93

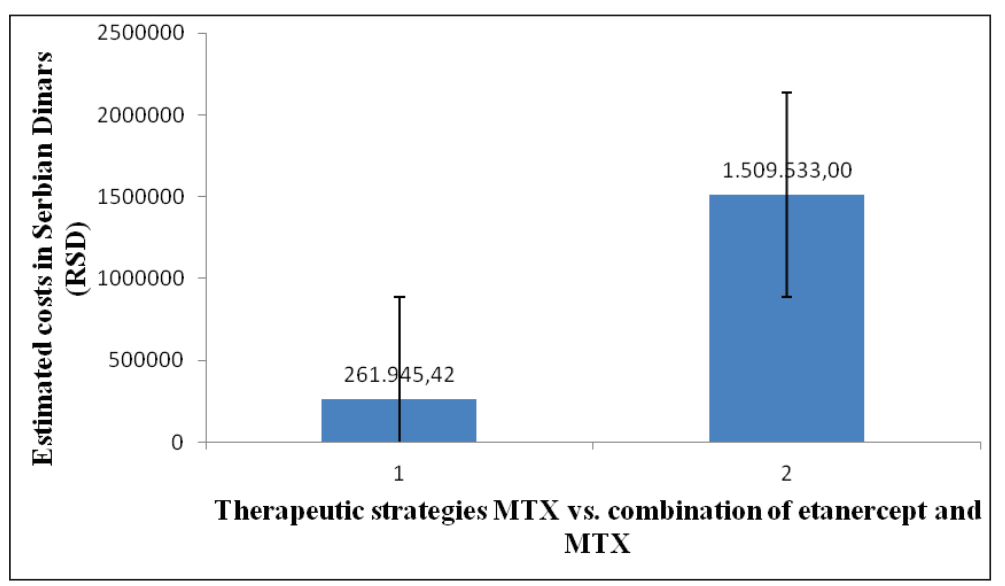

Figure 1. Total costs for one year of treatment (2009-2010) per patient for MTX monotherapy and a combination of etanercept and methotrexate

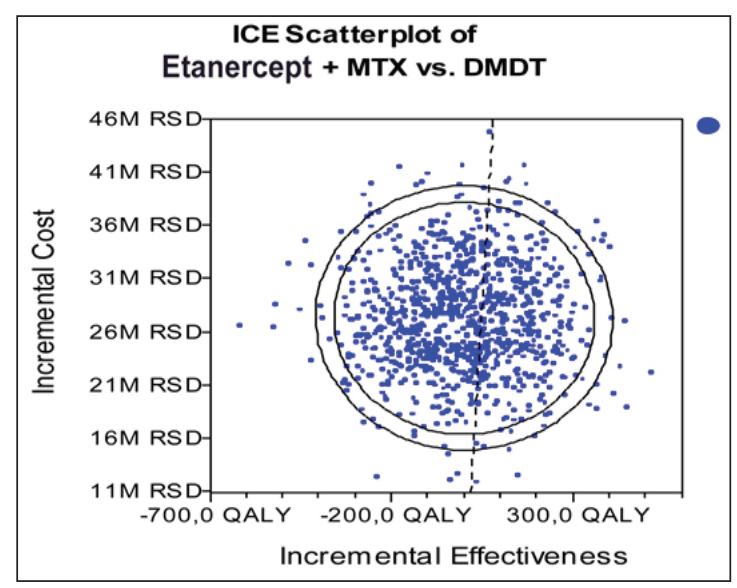

Figure 2. Distributions of the incremental cost-effectiveness ratio (ICER) calculated using Monte Carlo simulations for the total costs per quality-adjusted life years (QALY) for etanercept in combination with methotrexate and MTX monotherapy 
Table 1. Distribution of the incremental cost-effectiveness ratios (ICERs) calculated using Monte Carlo simulations (using a cohort of 1,000 virtual patients) for the total costs per QALY shown in Figure 2.

\begin{tabular}{|c|c|c|c|c|c|c|}
\hline $\begin{array}{l}\text { Therapeutic } \\
\text { strategy }\end{array}$ & Costs (RSD) & Difference in costs & Effectiveness & $\begin{array}{l}\text { Difference in ef- } \\
\text { fectiveness }\end{array}$ & $\begin{array}{l}\text { Cost/effectiveness } \\
\text { ratio } \mathrm{C} / \mathrm{E}\end{array}$ & $\begin{array}{l}\text { Incremental cost- } \\
\text { effectiveness ratio } \\
\text { Incr } C / E \text { (ICER) }\end{array}$ \\
\hline $\begin{array}{l}c D M A R D-d \\
(M T X)\end{array}$ & 7.788.768,97 RSD & & 5.38 QALY & & $\begin{array}{l}\text { 1.446.640, } 78 \text { RSD/ } \\
\text { QALY }\end{array}$ & \\
\hline $\begin{array}{l}\text { Etanercept }+ \\
\text { MTX }\end{array}$ & 3.487.470, 29 RSD & 27.081.701, 32 RSD & 5.93 QALY & 0.54 QALY & $\begin{array}{l}5.882 .714,57 \text { RSD/ } \\
\text { QALY }\end{array}$ & $\begin{array}{l}\text { 49.821.232, } 70 \text { RSD/ } \\
\text { QALY }\end{array}$ \\
\hline
\end{tabular}

QALY when the patient was treated with etanercept and MTX, while for monotherapy with MTX, the total effectiveness was 5.38 QALY.

The results of the cost-effectiveness analysis are shown in Table 1.

For etanercept in combination with MTX, the calculated ICER (with only methotrexate as the baseline comparator) for the majority of virtual patients was on the left side of the willingness-to-pay line, which indicates that this type of biological therapy for RA in the socioeconomic environment of Serbia is not cost effective.

The results of the sensitivity analysis indicate that variables from the model related to the severe form of RA with HAQ state greater than 2.1 are present more than other variables. As they change, the value of the net monetary benefit becomes negative, within the range of -7.3 to -2.8 million Serbian dinars, which makes our conclusion susceptible to changes in costs and treatment effects of etanercept in patients with more severe forms of $\mathrm{R}$.

\section{DISCUSSION:}

The benefits of biological DMARDs in patients with RA have been proven in numerous clinical studies (19-22). Due to the chronic and progressive course of RA, lifelong treatment with biological drugs is associated with increased burden of RA, not only in countries in the Balkan region but also in countries with stable economies. NICE recommends prescribing these drugs only in cases where therapy with cDMARDs has failed, with continuous monitoring due to the potential side effects of these drugs. The EULAR recommendations are based on the new concept of treating RA, where achieving remission should be followed by a reduction in dose of bDMARDs $(2,23)$. The new goal in treating RA is discontinuation of bDMARDs in remission, which should result in decreased side effects and costs of treating RA (1).

The efficacy of etanercept in combination with MTX was proven in recent literature, where etanercept demonstrated beneficial effects, such as radiological and clinical responses $(20,21,24)$.Our results indicate that the total cost of treating RA with etanercept in combination with MTX is on average 1.509.533, 002 RSD (12.178, 26 Euro), which is lower than the results from the USA (25-27). Due to the high costs of bDMARDs, the use of etanercept or similar drugs within the Serbian health system is not part of regular clinical practice, and it is limited by restrictive guidelines, which are common in the health systems of European countries (28).

The results of our model indicate that etanercept in combination with MTX compared to monotherapy with MTX is not a cost-effective therapeutic strategy, despite the higher gain since the costs of etanercept plus MTX are higher. In similar studies in countries with higher thresholds, etanercept was also not a cost-effective therapeutic strategy for most scenarios in patients with RA. TNF inhibitors have favourable cost-effectiveness ratios when the threshold is from 50000 to $100000 € /$ QALY, and if the threshold is $35000 € /$ QALY, rituximab is the most cost-effective alternative among biologics in the patients with an insufficient response to TNF inhibitors $(13,28)$

In the socioeconomic sphere of Serbia, the gain of etanercept in patients with RA is not related to cost savings. The main reason for this outcome is that the prices of medicine are regulated by pharmaceutical companies and are similar in Serbia and in developed European countries, but the prices of health care services are 10-100 times lower in Serbia country than in developed European countries. This duality in the process of price allocation makes the cost-effectiveness of biological drugs unfavourable for the health systems in the Balkan countries, which are undergoing socioeconomic transition.

In the circumstances of the decreasing the price of etanercept, we would expect that etanercept would reach the point of an advantageous cost-effectiveness ratio.

\section{CONCLUSIONS}

To make the cost-effectiveness ratio of biological drugs such as etanercept more favourable international pharmaceutical companies need to create special pricing strategies for these drugs based on local pharmacoeconomic studies. Further surveys are needed to identify the portion of the population of patients with RA where etanercept could be an effective therapeutic strategy with cost savings.

\section{Acknowledgements}

This study was partially funded by grant No 175007 from the Serbian Ministry of Education, Science and Technological Development. 


\section{REFERENCES}

1. Tanaka Y. Current concepts in the management of rheumatoid arthritis. Korean J Intern Med. 2016;31(2):210-8.

2. Smolen JS, Aletaha D, McInnes IB. Rheumatoid arthritis. Lancet. 2016; (16)30173-8.

3. Alamanos Y, Voulgari PV, Drosos AA. Incidence and prevalence of rheumatoid arthritis, based on the 1987 American College of Rheumatology criteria: a systematic review. Semin Arthritis Rheum. 2006;36(3):182-8.

4. Sokka T, Kautiainen H, Pincus T, et al. Work disability remains a major problem in rheumatoid arthritis in the 2000s: data from 32 countries in the QUEST-RA study. Arthritis Res Ther. 2010;12(2):R42.

5. Cross M, Smith E, Hoy D, et al. The global burden of rheumatoid arthritis: estimates from the global burden of disease 2010 study. Ann Rheum Dis. 2014;73(7):1316-22.

6. Banal F, Dougados M, Combescure C, Gossec L. Sensitivity and specificity of the American College of Rheumatology 1987 criteria for the diagnosis of rheumatoid arthritis according to disease duration: a systematic literature review and meta-analysis. Ann Rheum Dis. 2009;68(7):1184-91

7. Aletaha D, Neogi T, Silman AJ, Funovits J, Felson DT, Bingham CO. 2010 Rheumatoid arthritis classification criteria: an American College of Rheumatology/European League Against Rheumatism collaborative initiative. Arthritis Rheum. 2010;62(9):2569-81.

8. Smolen JS, Breedveld FC, Schiff MH, et al. A simplified disease activity index for rheumatoid arthritis for use in clinical practice. Rheumatology (Oxford). 2003;42(2):244-57

9. Bruce B, Fries JF. The Arthritis, Rheumatism and Aging Medical Information System (ARAMIS): still young at 30 years. Clin Exp Rheumatol. 2005;23(5Suppl 39): 163-7

10. Schett G, Stach C, Zwerina J, Voll R, Manger B. How antirheumatic drugs protect joints from damage in rheumatoid arthritis. Arthritis Rheum. 2008;58(10):2936-4811.

11. Lopez-Olivo MA, Siddhanamatha HR, Shea B, Tugwell P, Wells GA, Suarez-Almazor ME. Methotrexate for treating rheumatoid arthritis. Cochrane Database Syst Rev.2014 10;(6):CD000957.

12. Tree Age Pro. Healthcare software. Tree Age Software Inc [release 2005,1998-2005]. Available from: www. softscout.com/software/healthcare-and-Human Services/Diagnosis

13. Kobelt G, Lindgren P, Singh A, Klareskog L. Cost effectiveness of etanercept (Enbrel) in combination with methotrexate in the treatment of active rheumatoid arthritis based on the TEMPO trial. Ann Rheum Dis. 2005;64(8):1174-9.

14. St. Clair EW, Pisetsky DS, Haynes BF. Rheumatoid arthritis.Philadelphia: Lippincott Williams \& Wilkins; 2004.

15. Tariff book of health care services in health facilities of Republic of Serbia. Belgrade: Republic Institute for Health Insurance; 2008.
16. The World Bank. Data and Statistics. Available from: hptt://web.worldbank.org./wbsite/external/datastatistics/0. [updated 2010 September 12].

17. Drummond MF, Barbieri M, Wong JB. Analytic choices in economic models of treatments for rheumatoid arthritis: What makes a difference? Med Decis Making.2005;25(5):520-33.

18. Weinstein MC, O'Brien B, Hornberger J, et al. ISPOR Task Force on Good Research Practices--Modeling Studies. Principles of good practice for decision analytic modeling in health-care evaluation: report of the ISPOR Task Force on Good Research Practices-Modeling Studies. Value Health. 2003 ;6(1):9-17

19. Cohen SB, Emery P, Greenwald MW, et al. Rituximab for rheumatoid arthritis refractory to anti-tumor necrosis factor therapy: Results of a multicenter, randomized, double-blind, placebo-controlled, phase III trial evaluating primary efficacy and safety at twenty-four weeks. Arthritis Rheum. 2006;54(9):2793-806.

20. Combe B, Codreanu C, Fiocco U, et al. Efficacy, safety and patient-reported outcomes of combination etanercept and sulfasalazine versus etanercept alone in patients with rheumatoid arthritis: a double-blind randomised 2-year study. Ann Rheum Dis. 2009;68(7):1146-52

21. Jones G, Sebba A, Gu J, et al. Comparison of tocilizumab monotherapy versus methotrexate monotherapy in patients with moderate to severe rheumatoid arthritis: the AMBITION study. Ann Rheum Dis. 2010;69(1):88-96.

22. Nagy G, van Vollenhoven RF. Sustained biologic-free and drug-free remission in rheumatoid arthritis, where are we now? Arthritis Res Ther. 2015;17:181.

23. Klareskog L, van der Heijde D, de Jager JP, et al. TEMPO (Trial of Etanercept and Methotrexate with Radiographic Patient Outcomes) study investigators. Therapeutic effect of the combination of etanercept and methotrexate compared with each treatment alone in patients with rheumatoid arthritis: double-blind randomised controlled trial. Lancet. 2004;363(9410):675-81.

24. Greenapple R. Trends in biologic therapies for rheumatoid arthritis: results from a survey of payers and providers. Am Health Drug Benefits. 2012;5(2):83-92.

25. Howe A, Eyck LT, Dufour R, Shah N, Harrison DJ. Treatment patterns and annualdrug costs of biologic therapies across indications from the Humana commercial database. J Manag Care Spec Pharm. 2014;20(12):1236-44.

26. Lambert CM. Medical therapy for rheumatoid arthritis--value for money? Rheumatology (Oxford). 2001;40(9):961-4.

27. Kobelt G, Kasteng F. Access to innvative treatments in rheumatoid arthritis in Europe. A report prepared for the Europian Federation of Pharmaceutical Industry Associations (EFPIA); 2009

28. Joensuu JT, Huoponen S, Aaltonen KJ, Konttinen YT, Nordström D, Blom M. The cost-effectiveness of biologics for the treatment of rheumatoid arthritis: a systematic review. PLoS One. 2015;10(3):e0119683. 